\title{
Current society and education
}

\section{Sociedad actual y la educación}

DOMINGUEZ-LUGO, Alma Jovita†*, CORTES-MORALES, Griselda, CASTORENA-PEÑA, Abraham and SALAZAR-GAITAN, Pablo Arturo

Universidad Autónoma de Coahuila, Faculty of Mechanical and Electrical Engineering, Mexico.

ID $1^{\text {st }}$ Author: Alma Jovita, Dominguez-Lugo / ORC ID: 0000-0003-4988-4911, CVU CONACYT ID: 260410

ID $1^{\text {st }}$ Coauthor: Griselda, Cortes-Morales / ORC ID: 0000-0002-2567-7056, CVU CONACYT ID: 617827

ID $2^{\text {nd }}$ Coauthor: Abraham, Castorena-Peña / ORC ID: 0000-0002-8833-1159, CVU CONACYT ID: 411532

ID $3^{\text {rd }}$ Coauthor: Pablo Arturo, Salazar-Gaitan

DOI: $10.35429 /$ JSEM.2020.21.7.8.12

Received July 10, 2020; Accepted December 29, 2020

\begin{abstract}
The current life of young people is quite different from the one their parents lived where libraries were visited, encyclopedias were consulted, etc. Today they live in a world where everything is new, where technologies embrace maintenance and increasingly want to have more and more modern things; but at the same time they are so immersed in that world that without thinking, they are leaving the directions behind. The same society has modified the teaching processes, so that it has been diminished in a matter of attention and commitment by the students. To be up-to-date, ubiquitous education arose long ago, where information technologies enter teachinglearning techniques. In this article, an analysis of indicators was carried out that allows an overview of how students are affected by the society in which they live and when different types of education are available.
\end{abstract}

Education, Technology, Liquid society

\begin{abstract}
Resumen
La vida actual de los jóvenes es por mucho muy diferente a la que vivieron sus padres en donde se visitaban las bibliotecas, se consultaba en enciclopedias, etc. Hoy viven en un mundo donde todo es novedad, donde las tecnologías los mantiene abrazados y cada vez quieren tener más y más cosas modernas; pero a la vez están tan inmersos en ese mundo que, sin pensarlo, están dejando atrás las responsabilidades. La misma sociedad, ha modificado los procesos de enseñanza, de manera que se ha visto mermada en cuestión de atención y compromiso por parte de los estudiantes. Para poder estar al día, hace tiempo surgió la educación ubicua en donde las tecnologías de la información se adentran en técnicas de enseñanza aprendizaje. En este artículo, se realizó un análisis de indicadores que permitieran tener una visión general de cómo se ven afectados los alumnos por la sociedad en la que viven aun y cuando se cuenta con diversos tipos de enseñanza.
\end{abstract}

Educación, Tecnología, Sociedad líquida

Citation: DOMINGUEZ-LUGO, Alma Jovita, CORTES-MORALES, Griselda, CASTORENA-PEÑA, Abraham and SALAZAR-GAITAN, Pablo Arturo. Current society and education. Journal of Systems and Educational Management. 2020. 7-21:8-12.

\footnotetext{
*Correspondence to author (Email: almadominguez@uadec.edu.mx)

$\dagger$ Researcher contributing as first Author.
} 


\section{Introduction}

Today technology is "essential" to survive, but if we talk about education, there are factors that interfere when being in the teaching - learning process.

For many years the phrase "Who has the information has the power" has been heard and read, if "Information is power" - a thought that some attribute to Francis Bacon - who has the upper hand is not the one who knows where to find certain data, antecedent, source or material, but rather who knows how to use what they found. (Bit, 2019) And seeing the above, most of the students who make use of technologies are for issues other than education, and when they do, not all are careful to verify that they are from reliable sources; This means that they are in a hurry to start tasks only, forgetting that quality is important and requires permanent work and vigilance (León, 2007).

For this reason, it is important that students know the source from which they obtain the information, since the quality of their work is essential, so if we talk about Quality in Education, it is to talk about several dimensions:

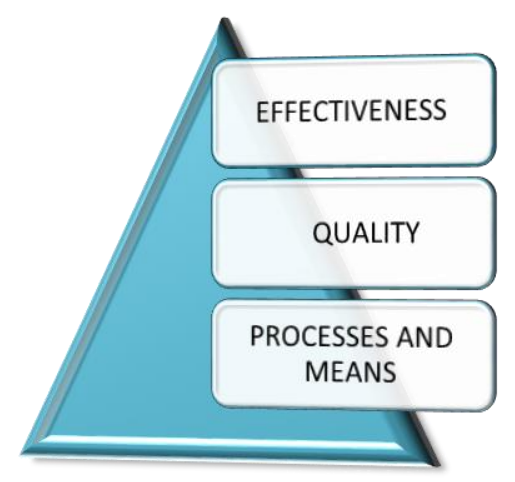

Figure 1 Dimensions of Education

Efficiency makes students really learn what they are supposed to learn.

Quality is one whose contents respond adequately to what the individual needs to develop as a person-intellectually, emotionally, morally and physically, and to act in the various spheres of society, the political, the economic, the social. (Yzaguirre Peralta, 2005). Finally, the dimension that refers to the processes and means, offers the student an adequate physical context for learning, prepared teachers, study and work materials, adequate didactic strategies, Information Technologies used correctly, etc.
For some years now, students have been accompanied in their educational life by Information Technologies.

\section{Information technology}

The evolution of Information and Communication Technologies and, particularly, the incorporation of electronic mobile computing devices, laptops, tablets, smart phones, among others; In daily life, they have generated great changes in the way people interact and the development of their activities, which has permeated areas as diverse as: education, health, financial, environmental, industry, among others.

One of the areas, in which great changes have been generated, is in education. The incorporation of technologies in the educational field is becoming more and more necessary, given that the new generations have incorporated technology in an almost natural way, generating new challenges and fostering new scenarios where its use is a mechanism to support the process of acquisition of new knowledge, either in a formal process or in an informal process. (Cabero Almenara, 2010).

The challenge posed by the use of technologies to support teaching-learning processes has generated the need to create new ways of carrying them out, which forces us to make changes in the way of educating.

Due to these changes, the teacher's profile also changed significantly, he stopped being the specialist and became the learning intermediary. The center of the educational scene is no longer occupied only by the teacher, but by the teacher and his students, all of whom become partners and co-participants in the same process. The teacher must motivate and incentivize the student, it is a bridge between the learner and the learning and collaborates so that the student reaches her objectives.

This leads them to explore new learning environments with their students, master the use of information technologies, value the collective learning process and reorganize the evaluation process. 
Learning is a process that allows us to acquire knowledge and skills according to the needs that the person presents and these in turn based on the challenges that external or internal factors encourage us to learn something every day. This learning as the years go by is no longer empirical and is obtained little by little by perfecting them in educational centers. (Guaña, Ramírez, Mariño, \& Ávila, 2020)

Education has evolved in the way it presents itself to students:

\begin{tabular}{|ll|}
\hline- & $\begin{array}{l}\text { Traditional education (takes place in a } \\
\text { classroom) }\end{array}$ \\
\hline- & $\begin{array}{l}\text { Distance education (it takes place in a non-face- } \\
\text { to-face way part of the time and is carried out } \\
\text { through the use of technologies such as television, } \\
\text { radio and printed support material) }\end{array}$ \\
\hline- & $\begin{array}{l}\text { Online education (is done through the use of a } \\
\text { computer and with the support of a computer } \\
\text { platform) }\end{array}$ \\
\hline- & $\begin{array}{l}\text { U-learning (ubiquitous learning) understanding } \\
\text { this concept as "ubiquitous training integrates }\end{array}$ \\
learning and ubiquitous technology within a \\
training strategy.
\end{tabular}

Table 1

In education, the term at a distance, or online programs, is often promoted for the convenience that asynchronous classes offer to adapt to personal agendas and that allow studying and completing tasks adjusting to one's own schedules.

This has generated a profound change in the expectations that these courses and programs arouse; student-consumers expect an even higher level of personalization and adaptation to their preferences, not only in terms of schedules. As "clients" that they are, they know that they can contract their educational services elsewhere. (Bubbles, 2014)

\section{Present}

Education has been changing in terms of teaching, content, location, and schedules. Therefore, it can be said that there is no "old" school on the one hand and young Internet users on the other. Different realities and rhythms are presented according to the school spaces, the positioning of the actors and the realities of the culture.
There are schools that work with new pedagogies and with curricula that are being renewed to make room for new knowledge in dialogue with new social dynamics; anyone visiting a school will see that project work and inquiry learning is much more common than typical early 20 th century lectures.

On the other hand, even when it is necessary to attend to the challenges that Bauman raises regarding the form, content and school learning, they must be thought of from concrete action frames and not as totalizing and universal diagnoses.

The "liquid school" is not the same in the metropolises as in the peripheries, in contexts with networks of economic well-being and legal security than in other politically unstable and economically precarious ones. (Pulfer \& Dussel, 2018).

It is necessary to raise the quality of education, improve the relevance of programs and generate information systems on available skills is important. Articulate educational and vocational training systems in a concept that makes the idea of education and skills development a reality throughout life. (Espinoza Mina \& Gallegos Barzola, 2020)

\section{Design of the investigation}

Zygmunt Bauman, mentioned that modernity became, according to the term successfully coined by him, liquid. "Today the main concern of our social and individual life is how to prevent things from becoming fixed, that they are so solid that they cannot change in the future. We do not believe that there are definitive solutions and not only that: we do not like them. (Barranco, 2017)

Young students are used to living quickly, sure that things don't last long, sure that new opportunities will appear that will make existing ones obsolete. Based on the new way of taking classes, and above all, wanting to know what their thoughts are towards their future and how they influence the education process, this research was carried out which focuses on some concepts originated by the current liquid society . And it will result in the interpretation of reality in addition to explaining why and for what purpose of the object of study; in order to expand the "What?" of research and the "how?" 
A group of university students were presented with the concepts in table 2, and they were asked to weigh from 1 to 5 , depending on their feelings in the educational life they are currently studying. The concepts evaluated in the survey were:

1.- Lack of commitment, in education

2.- Low loyalty, the university no longer feels part

3.- It is seen as a product, because I need the Title

4.- It is disposable, because it will not apply the knowledge

Table 2 Concepts evaluated by students

The survey method was the tool used for the research, which will be classified by variables that will give the trends. Each of these points will be evaluated and later the variables will be crossed to achieve indicators that allow decision-making. The results will be based on the Likert scale.

\section{Results}

Of the students surveyed, Graphic 1 shows that a large number thinks that what is seen at the University will not be applied in future work, thus creating an area of opportunity for the same institution in order to change that opinion through reforms curricula based on what employers require, without leaving aside new methodologies to attract the attention of students and thus achieve feeling part of the educational world. On the other hand, a significant number indicates that they only go for the title, since they are working in the industrial sector and require it to move up in the category

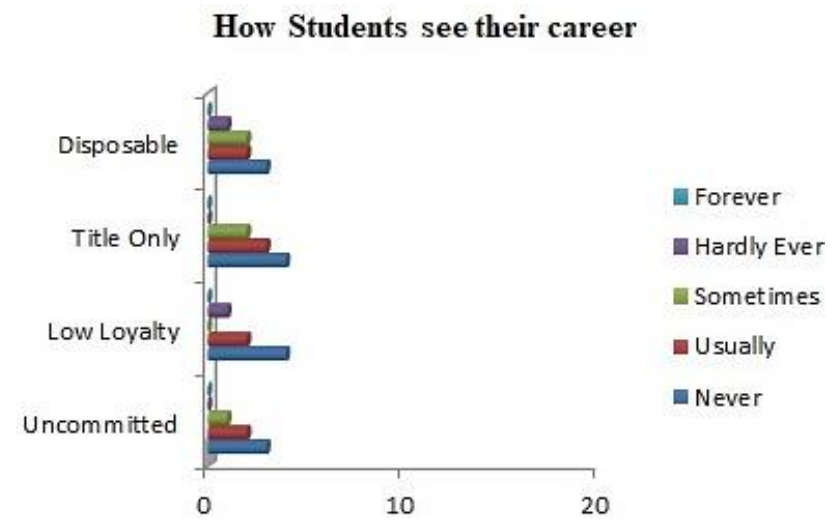

Graphic 1 Result of the questions, on how students see their career
In the same way, the order of the concepts that they consider is affecting their education, Society, Politics, Modern Man and Accelerated Time was asked.

Within Graphic 2, it can be noted that living quickly is affecting them, changes in education, modernity, updates, etc., in addition to feeling pressured by modern man, since they must always be up to date with the technological updates and learn about new ways of working and educating oneself.

\section{Do you think it affects your education?}

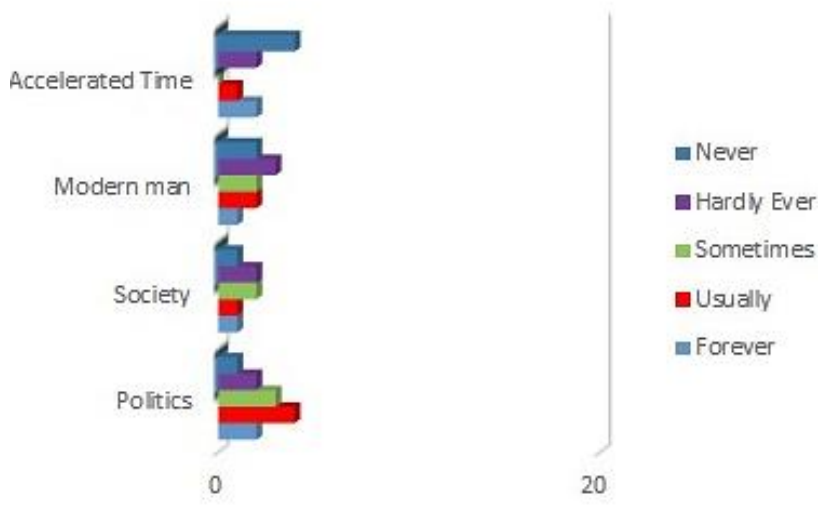

Graphic 2 Result of the questions, on how university students see their passage through the university

\section{Conclusions}

It is derived that young people are overwhelmed by modern man, where the world advances so fast that they are in need of learning more and more new things at such an accelerated speed that they feel the program content in which they are not enough is not enough. Are developing.

On the other hand, the political situation that accompanies the country affects education in certain aspects, as it is affected by government support that is suddenly offered and then ceases to exist.

Based on the results obtained, it is shown that it is important to improve the quality of the teaching-learning process, since the results show that students are not completely committed to their education, and are only wishing that time advances and they can have the college degree. 


\section{Recommendations}

It is important that teachers have a large participation, so that the world in which young people are developing is understood, in a world where the forms of teaching have changed and of which some teachers still resist the change of the current educational model.

Teachers and students must be motivated to use technologies for the good of education, thus allowing to maintain the advantages of the educational model, which is based on the four pillars of education, working on the basis of evaluations by project, case studies, in addition to eliminating the techniques that students consider "obsolete", all with the good purpose of achieving a highly proactive attention on both sides.

\section{References}

Baez Pérez, C., \& Clunie Baufond, C. E. (s.f.). Una mirada a la Educación Ubicua. aAIESAD.

Barranco , J. (2017). Pero ¿Qué es la Sociedad Líquida? La Vanguardia.

Bit, E. d. (2019). Obtenido de https://eldiariodelbit.blogspot.com/2014/03/qui en-tiene-la-informacion-tiene-el.html

Burbules, N. (2014). Los significados del Aprendizaje Ubicuo. epaa/aape.

Cabero Almenara, J. (2010). Los retos de la Integración de las TICs en los procesos educativos. Perspectiva Educacional.

Espinoza Mina, M. A., \& Gallegos Barzola, D. (10 de mayo de 2020). Habilidades blandas en la educación y la empresa: Mapeo Sistemático. Uisrael, 7(2).

Guaña, B. E., Ramírez , P. T., Mariño, C. H., \& Ávila, P. Y. (Marzo de 2020). Factores que influyen en la educación continua desde la perspectiva del profesional de enferemería. Sinapsis, 1(16).

León, A. (2007). Qué es la Educación. Red de Revistas Científicas de América Latina, el Caribe, España y Portuga.

Pulfer, D., \& Dussel, I. (2018). La Escuela : Líquida o Liquidada? EDUforics.
Yzaguirre Peralta, L. E. (2005). Calidad Educativa ISO 9001-2000 en México. Revista Electronica Iberoamericana sobre Calidad, Eficacia y Cambio en Educación. 